Int. J. Dev. Biol. 52: 1143-1150 (2008)

doi: $10.1387 / \mathrm{ijdb} .072561 \mathrm{gk}$

\title{
Mouse G-protein $\gamma 3$ expression in the developing CNS and neural crest cell derivatives
}

\author{
GREGORY M. KELLY1,2,*, YUKIO SAIJOH ${ }^{3}$, ARIEL FINKIELSZTEIN ${ }^{1}$ and STEVE MANGOS ${ }^{1, \#}$ \\ ${ }^{1}$ Department Biology, Molecular Genetics Unit, ${ }^{2}$ Department of Paediatrics, University of Western Ontario, London, ON Canada and \\ ${ }^{3}$ Department of Neurobiology \& Anatomy, University of Utah School of Medicine, Salt Lake City, UT, USA
}

\begin{abstract}
Heterotrimeric G-protein signaling, involving $\alpha, \beta$ and $\gamma$ subunits, plays a number of roles in differentiation and development. Individual $\gamma$ subunits interact with a $\beta$ subunit and as a heterodimer, is responsible for modulating many $\mathrm{G}$ protein-mediated cellular responses. The 12 $\gamma$ subunits in mammals have highly variable distribution and expression patterns in adult tissues. $\gamma 3$ is abundantly and widely expressed in the brain and when its expression is knocked-out, the mice show increased susceptibility to seizures, reduced body weights and decreased adiposity compared to the wild-type littermates (Schwindinger et al., 2004). Recent evidence has shown the Gng3 gene being strongly induced in activated CD4+ T-cells (Dubeykovskiy et al., 2006) and its involvement in the developing mammalian enteric nervous system (Heanue and Pachnis, 2006). Given this diversity in expression and interest in finding models of human disease, and to extend our previous investigation with zebrafish $\gamma 3$ (Kelly et al., 2001), we undertook an analysis to report the temporal and spatial expression patterns of $\gamma 3$ mRNA during mouse embryogenesis. Analysis reveals that $\gamma 3$ transcripts were first expressed in mid-late embryonic stages. Specifically, signals were predominant in the CNS and in neural crest cell derivatives including but not limited to the trigeminal and dorsal root (spinal) ganglia, and in cells of the adrenal medulla. These data indicate that $\mathbf{G}$ protein coupled signaling involving $\gamma 3$ participates in a number of physiological roles, not only in the CNS, but also in numerous cells derived from the neural crest.
\end{abstract}

KEY WORDS: G-protein, gamma3, mouse, embryo, NCC

\section{Introduction}

Extracellular signals arriving at the cell surface in a variety of forms are transduced across the plasma membrane and initiate various cellular responses. This signal transduction is fundamental to all cells and in many cases it relies on G-protein coupled receptors (GPCRs) and a heterotrimeric complex composed of an $\alpha, \beta$ and $\gamma$ subunit. When the appropriate ligand binds to its GPCR a conformational change facilitates the binding of the GPCR to an $\alpha \beta \gamma$ heterotrimeric complex. Binding also allows the $\alpha$ subunit to exchange GDP for GTP and in this activated state G $\alpha$-GTP dissociates from the $\beta \gamma$ heterodimer, allowing both moieties to signal one or more downstream effectors. Attenuation of these intricate, often multi-tiered signaling cascades occurs when GTP is hydrolyzed and $\mathrm{G} \alpha$-GDP re-associates with the $\beta \gamma$ complex.

Signaling cascades involving G-proteins are not only funda- mental to normal cell physiology, but aberrant signaling leads to a number of diseases associated with tumorigenesis, endocrine disorders, cholera and whooping cough (Farfel et al., 1999, Gudermann et al., 2000, Marinissen and Gutkind, 2001, Morris and Malbon, 1999). Many elegant studies using tissue-cultured cells have functionally dissected the many facets of GPCR and Gprotein signaling, but by comparison few have concentrated on how G-protein-mediated signaling pathways function in the differentiation and development of a vertebrate embryo (see Malbon, 2005 for review). For instance, the G protein $\gamma 3$ subunit, which is expressed in the adult rat and mouse brain (Gautam et al., 1990, Kalyanaraman et al., 1995, Liang et al., 1998, Morishita et al.,

\footnotetext{
Abbreviations used in this paper: CNS, central nervous system; DIC, Differential interference contrast; GPCR, G-protein coupled receptor.
}

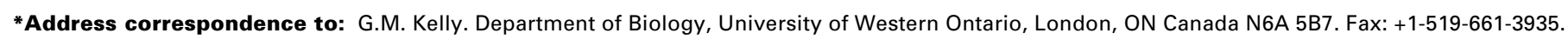
e-mail: gkelly@uwo.ca

\#Note: Currently at the Massachusetts General Hospital, Harvard Medical School. 
A

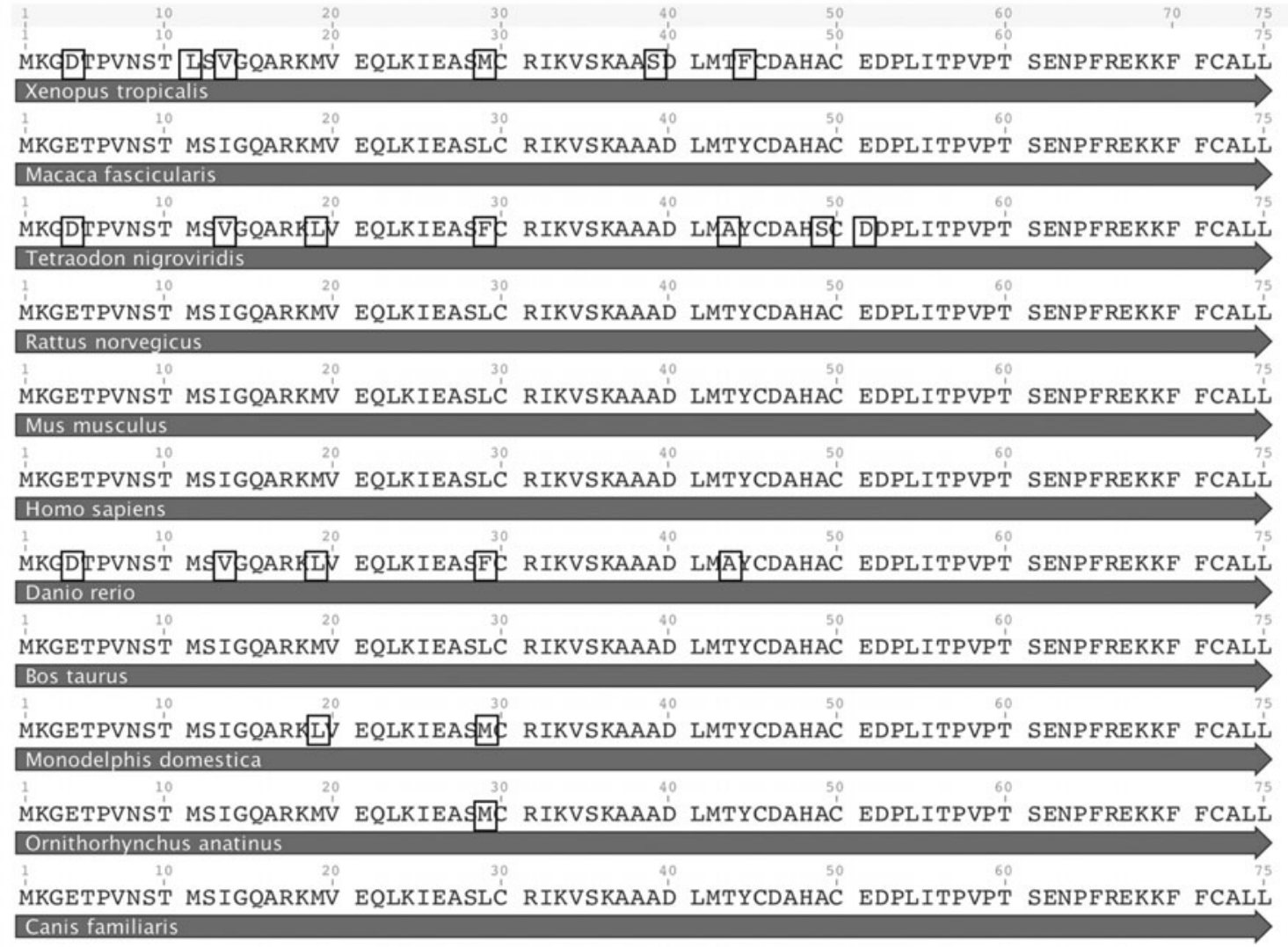

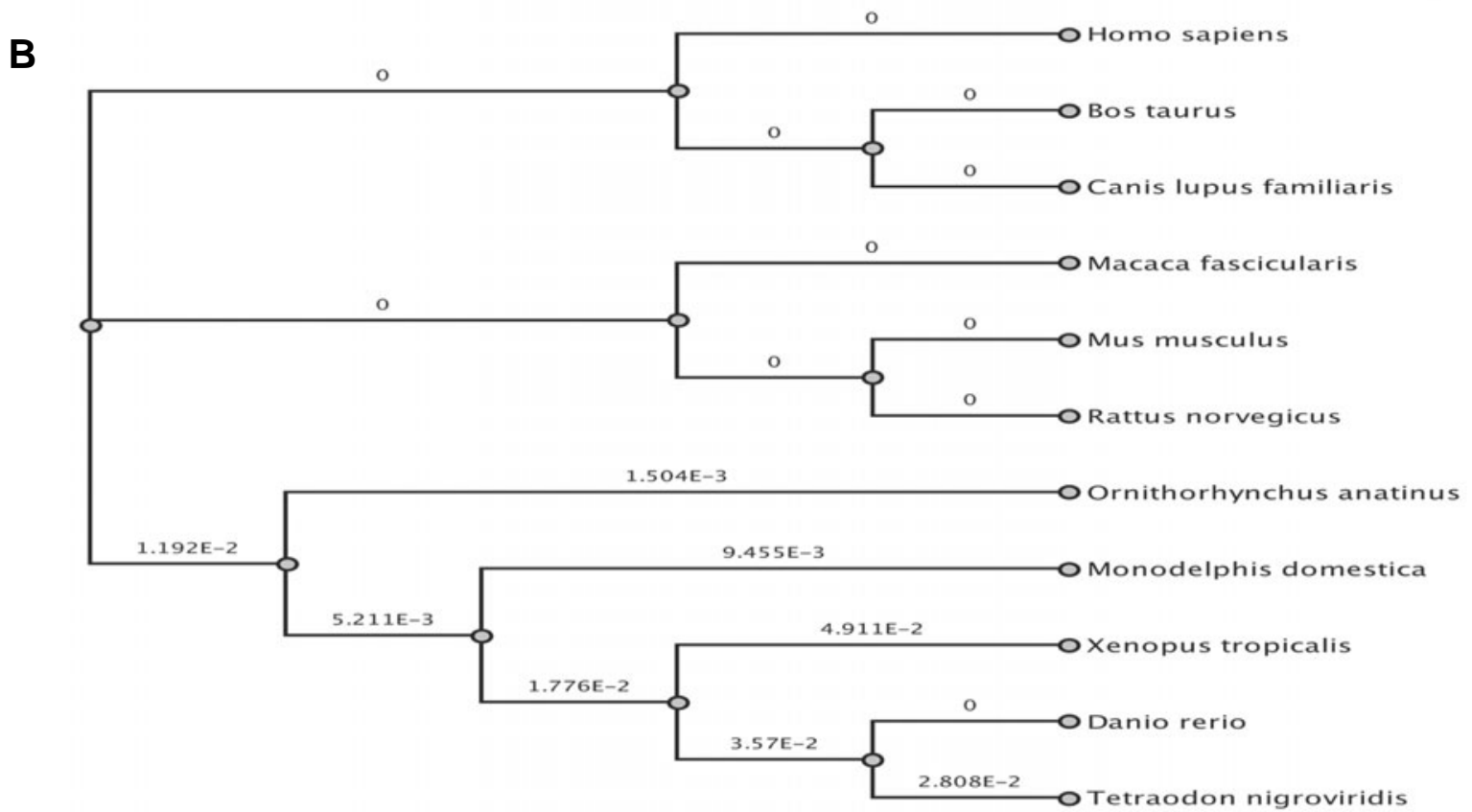

Fig. 1. Sequence identity of the G-protein $\boldsymbol{\gamma} \mathbf{3}$ subunit in different vertebrate animals. (A) Multiple sequence alignment (Drummond et al., 2007) of the G-protein $\gamma 3$ subunit from the Domestic Cow, (Bos taurus), NP_776498.1; Dog, (Canis familiaris), XP_540904.2; Zebrafish (Danio rerio), NP_571916.1; Human (Homo sapiens), NP_036334.1; Long-tailed Macaque (Macaca fascicularis), BAE90638.1; Gray Short-tailed Opossum (Monodelphis domestica), XP_001362378.1; Mouse, (Mus musculus), NP_034446.1; Duck-billed Platypus (Ornithorhynchus anatinus), XP_001506262.1; Norway Rat (Rattus norvegicus), EDM12732.1; Spotted Green Pufferfish (Tetraodon nigroviridis), CAG01580.1; Pipid Frog (Xenopus tropicalis), AAl35306.1. Boxes around individual amino acids represent changes from the conserved $\gamma 3$ sequence of higher mammals. (B) Cladogram, produced using the Geneious 3.5.2 software (Drummond et al., 2007), showing evolutionary relationships between $\gamma 3$ protein sequences. 


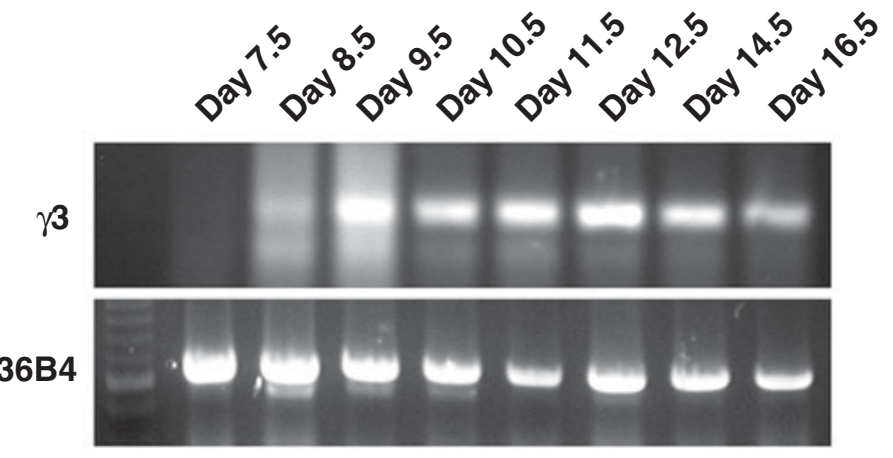

Fig. 2. RT-PCR showing G-protein $\gamma 3$ and $36 B 4$ expression in mouse embryos at day 7.5 through $\mathbf{1 6 . 5}$ p.c. The $\gamma 3$ amplicon of 320 base pairs is present from day 8.5 p.c. and onwards, whereas 36B4 (555 b.p.) is constitutively expressed at all stages examined. A 100 b.p. ladder is present on the left side of the 36B4 gel.

1997, Morishita etal., 1999, Schuller et al., 2001, Schwindinger et al., 2004), in rat taste cells, and in mouse testes, inner ear, T and B cells and enteric nervous system (Barritt et al., 1999, Downes et al., 1998, Dubeykovskiy et al., 2006, Heanue and Pachnis, 2006, Rossler et al., 2000), dimerizes with each of the five $\beta$ subunits (Yan et al., 1996), and is linked to signal transduction involving $\mathrm{Ca}^{2+}$ channels (Diverse-Pierluissi et al., 2000, Kleuss et al., 1993, Macrez et al., 1997, Macrez-Lepretre et al., 1997, Zhou et al., 2000). With gene targeting studies suggesting that mouse $\gamma 3$ functions in multiple brain regions and signaling pathways that control seizures, body weight and fat stores and a T-cell-dependent immune response (Dubeykovskiy et al., 2006, Schwindinger et al., 2004), it is surprising that the prerequisite spatial and temporal expression patterns have not been examined in embryos. Furthermore, accurate profiling of the cellular and molecular makeup of a tissue or organ is key to not only understanding its normal development, but also provides insight into the etiology of human disease (Heanue and Pachnis, 2006). Since cataloguing the distribution of specific G-protein subunits is a prerequisite step to address how G-protein signaling functions in devel- opment and to extend from our earlier report using the zebrafish as a model to study human disease associated with G-protein $\gamma$ subunits (Kelly et al., 2001), we investigated the spatial and temporal expression of $\gamma 3$ during mouse embryogenesis.

\section{Results and Discussion}

\section{Protein conservation and in silico analyses}

The G-protein $\gamma 3$ subunit has been cloned from the genomes of a number of animals and alignment of 11 mammalia, amphibia and actinopterygii (ray-finned fish) $\gamma 3$ sequences indicates that they share $87 \%$ identity and $96 \%$ similarity at the amino acid level (Fig. 1). In particular, all of the subunits contain the characteristic CALL motif at the C-terminus of the polypeptide. This motif is of great importance as it is the site where a prenyl group is post-translationally added to the poylpeptide, which occurs following the binding of a $\gamma$ to a $\beta$ subunit, and allows the heterodimer to be targeted to the endoplasmic reticulum prior to its subsequent anchorage at the plasma membrane (reviewed in Marrari et al., 2007). Dimerization between $\beta$ and $\gamma$ subunits is not dependent on isoprenylation (Schillo et al., 2004), but this lipidation is required for high affinity $\alpha-\beta \gamma$ and $\alpha-\beta \gamma$-receptor interactions and effector activation (Myung et al., 2006, Myung et al., 1999).

The $\gamma 3$ subunit from the Green Spotted Puffer Fish ( Tetraodon nigroviridis) is the most divergent of the group (Fig. 1B), and even then only 7 of the 75 amino acids differ between it and the mouse $\gamma 3$ subunit (Fig. 1A). It is interesting to note that the $\gamma 3$ subunits in the mammals are not identical, as the monotreme platypus (Ornithorhynchus anatinus) and the marsupial opossum (Monodelphis domestica) have 1 and 2 amino acid substitutions, respectively. The positioning of $M$. domestica on the cladogram (Fig. 1B), is therefore closer to non-mammalian clades, which does not fit with its true position on the evolutionary tree since it is the closest outgroup to the placental mammals (Mikkelsen et al., 2007). Nevertheless, given the high degree of identity between all the $\gamma 3$ subunits and the fact that mouse and zebrafish share $93 \%$ identity despite the lineages of the two being separated nearly 450 million years ago, it is not
A

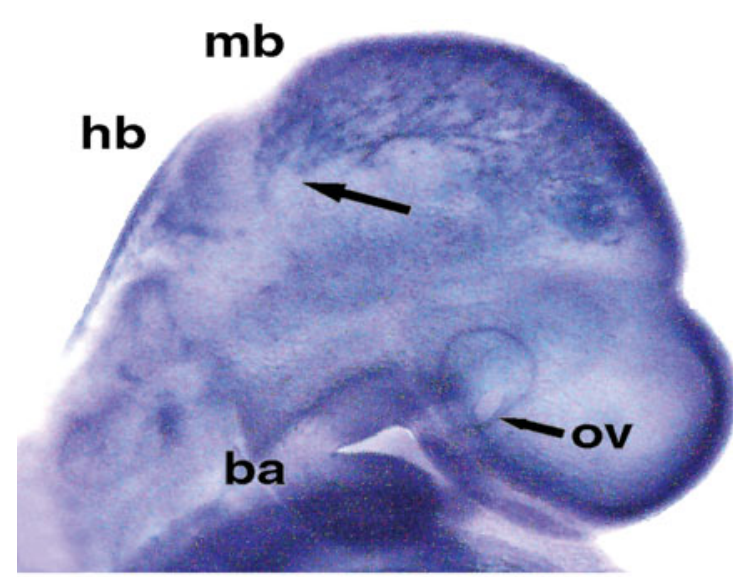

B

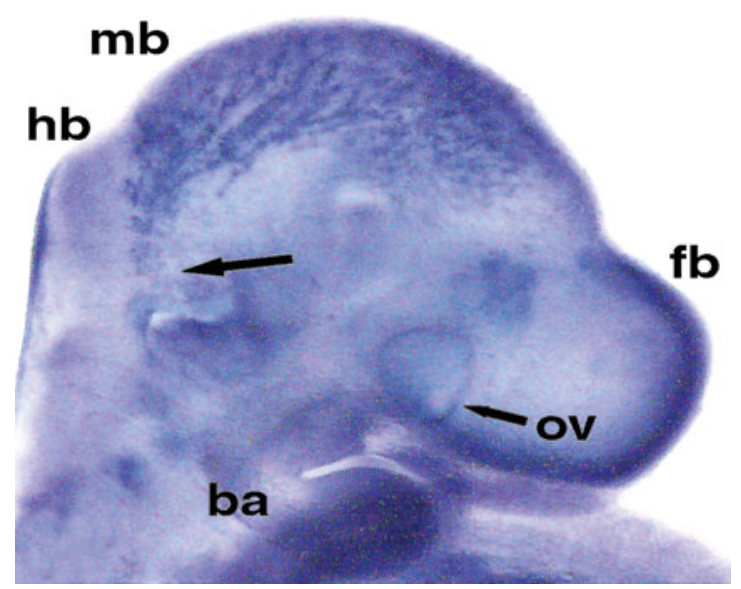

Fig. 3. Whole mount in situ hybridization showing G-protein $\boldsymbol{\gamma} \mathbf{3}$ expression patterns in mouse embryos at day 9-9.5 p.c. (A) Arrow denotes the extent of 3 mRNA expression in the midbrain. (B) At approximately 12 hours later (9.5 d.p.c.), other midbrain cells, immediately along the midbrainhindbrain junction, express $\gamma 3$ mRNA (arrow). Abbreviations: ba, branchial arch; fb, forebrain; hb, hindbrain; mb, midbrain; ov, optic vesicle. 


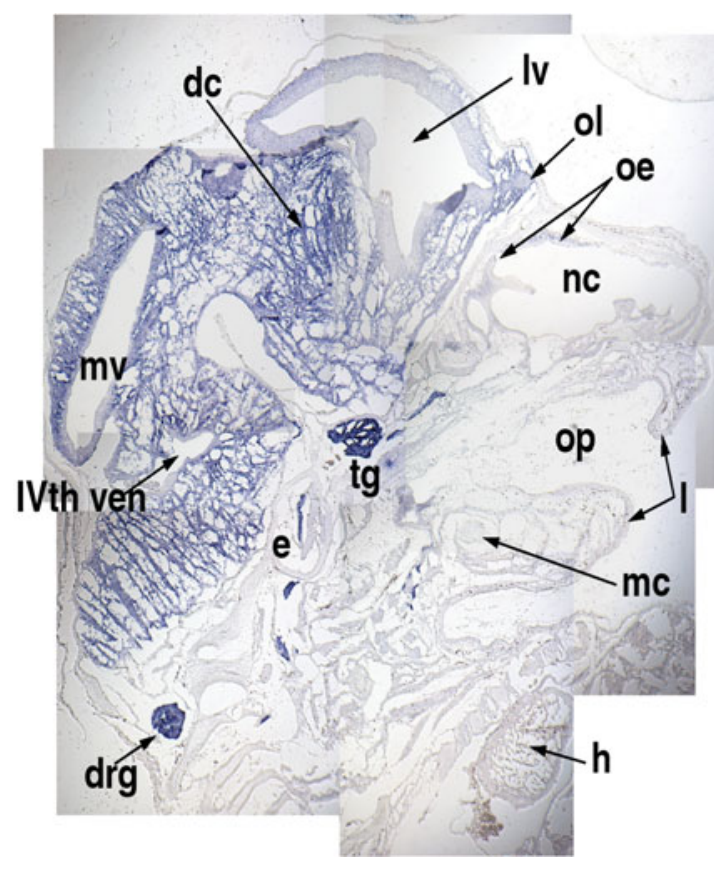

Fig. 4 (Left). Photomontage showing the $\gamma 3$ mRNA expression pattern in a day $\mathbf{1 4 . 5}$ p.c. mouse embryo. Differential interference contrast micrographs of midsagittal cryosections through the head reveals $\gamma 3$ signals localized to the brain, olfactory epithelium, trigeminal and dorsal root (spinal) ganglia. Signals are also present in the prospective ear. e, ear; dc, diencephalon; drg, dorsal root (spinal) ganglion; $h$, heart; I, lips; Iv, lateral ventricle; mc, Meckel's cartilage; mv, mesencephalic vesicle; nc, nasal cavity; oe, olfactory epithelia; ol, olfactory lobe; op, oropharynx; tg, trigeminal ganglion; IVth ven, IVth ventricle.
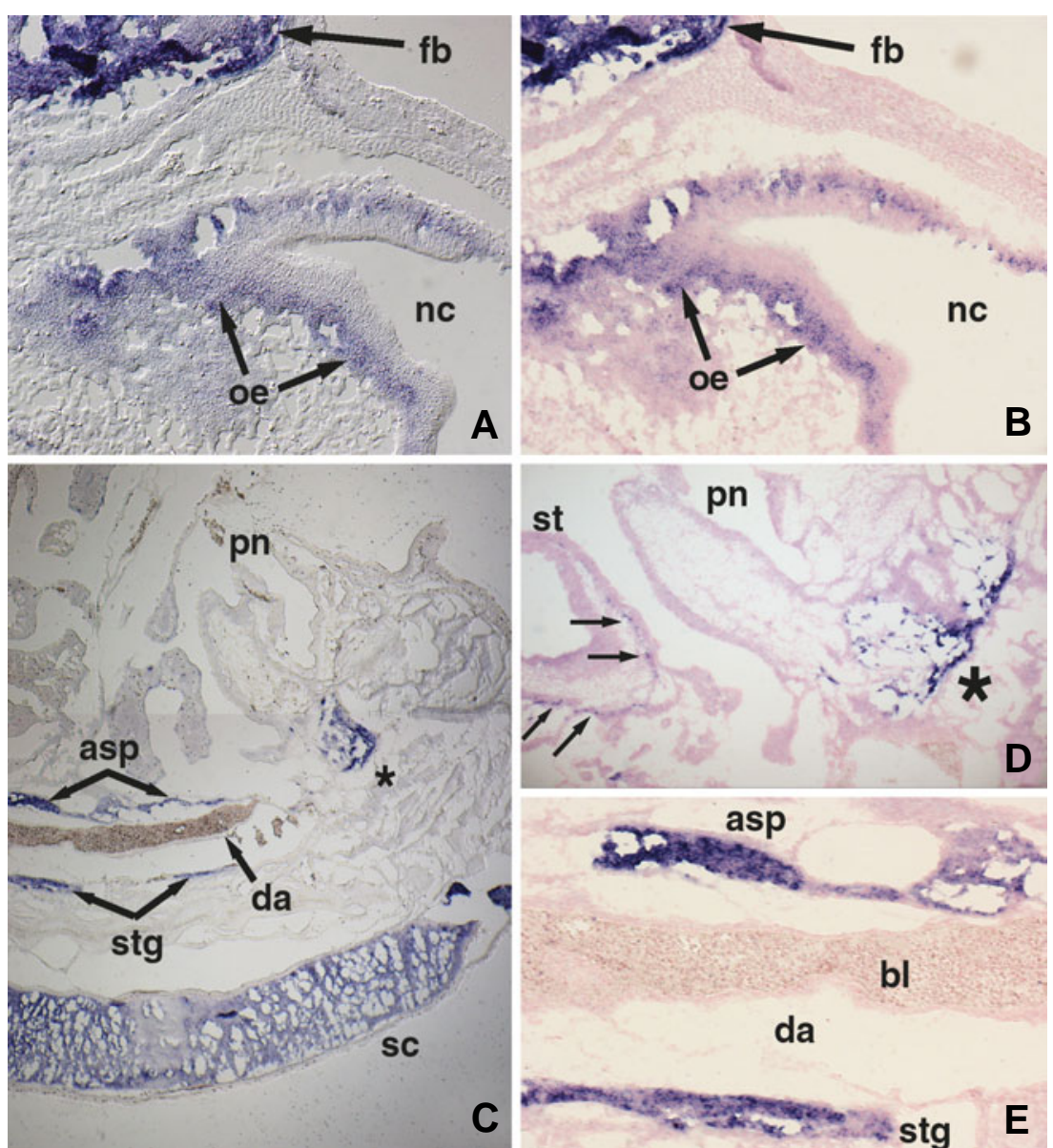

Fig. 5 (Right). Photomicrographs of cryosections showing $\mathbf{3} \mathbf{m}$ mNA expression in day $\mathbf{1 4 . 5}$ p.c. mouse embryos. (A) Differential interference contrast (DIC) image of a mid-sagittal section through the nasal cavity, showing expression in the brain and olfactory epithelia. (B) A brightfield image of the same section in (A), but counterstained with Nuclear Fast Red to show that $\gamma 3$ is expressed in the basal region of the olfactory epithelia. No signals are detected in cartilage. (C) DIC photomontage showing $\gamma 3$-expressing cells in the abdominal and tail region. The signal is enriched in the CNS and in the sympathetic ganglia. Similarly, the region at the base of the penis (asterisk) also contains cells that express $\gamma 3$. (D) Brightfield photomicrograph showing a Nuclear Fast Red stained section through the region at the base of the penis. Counterstaining reveals the punctate staining of $\gamma 3$-expressing cells in the stomach (arrows). (E) Brightfield image of a counterstained mid-sagittal section through the lower abdomen, showing the restricted expression of $\gamma 3$ in sympathetic ganglia flanking the descending (thoracic) aorta. asp, abdominal sympathetic ganglia; bl, blood; da, descending aorta; fb, forebrain; nc, nasal cavity; oe, olfactory epithelia; pn, penis; sc, spinal cord; st, stomach; stg, sympathetic trunk ganglia.

unreasonable to predict that the expression profiles would be similar between the two organisms.

\section{Temporal expression}

The temporal expression of mouse $\gamma 3$ was examined using an RT-PCR approach, but beforehand, an investigation to test the quality of the antisense and sense $\gamma 3$ probes and optimization of conditions for in situhybridization provided clues on the developmental timeline to focus the RT-PCR analysis. Briefly, stagespecific RNA was pooled from 2-3 embryos from different litters at mid-to-late stages, and then reverse transcribed into cDNA and used as template with $\gamma 3$-specific oligonucleotide primers in a PCR. To control for genomic contamination, primers were designed to span the intervening sequence between exons 2 and 3 of the Gng3 gene (Downes et al., 1998). Following the PCR the presence of an amplicon of 320 base pairs would be indicative of $\gamma 3$ expression at a particular stage of development. Even though signals were not seen by in situhybridization in embryos before day 8.5 p.c. (post-coitum), an aliquot of an embryonic day 7-7.5 p.c. cDNA library was used in the PCR to confirm that $\gamma 3$ transcripts were not present earlier, or below detectable levels using the in situapproach. The presence of a 320 base pair $\gamma 3$ amplicon was first seen at day 8.5 p.c. (Fig. 2), and the appearance of the amplicon corresponding to $36 B 4$, a constitutively expressed gene encoding an acidic ribosomal phosphoprotein (Krowczynska et al., 1989), indicated that day 7-7.5 p.c. cDNAs were available to serve as template in the PCR. Therefore, we are confident that the RT-PCR data depicts the bona fide expression profile of $\gamma 3$, which is not expressed at neural plate, pre-somite stages. This pattern of expression, appearing approximately mid-way through mouse embryogenesis was not predicted given the expression profile we reported in zebrafish (Kelly et al., 2001). In zebrafish embryos, 
expression appeared late at a time when the nervous system has already been regionalized, the brain segmented and neuronal differentiation in progress. The significance of the difference in onset of expression between mouse and zebrafish embryos is not known. Following embryogenesis, $\gamma 3$ is expressed in the postnatal mouse, at the post-hatching stage in zebrafish and in the adult of each animal (not shown).

\section{Spatial expression}

Having reported the temporal expression pattern of $\gamma 3$, the intent of the subsequent analysis was on determining whether or not transcripts were localized to specific regions in the embryo. In situ hybridization applied to whole mount embryos and cryosectioned material was used to examine the expression of $\gamma 3$ in embryos at embryonic day 7.5-16.5 p.c. Expression was first detected in the brain of embryos at day 8-8.5 p.c. Throughout development signals were predominately in the CNS (Figs. 3-5, 7 ). In day 9 embryos staining was confined to more dorsal, superficial layers of the midbrain (arrow, Fig. 3A). The overall pattern was maintained in day 9.5 embryos, except $\gamma 3$ expressing cells were now seen in more ventrolateral regions of the midbrain (arrow, Fig. 3B). No specific staining was seen in tissues of mesodermal or endodermal origin. In rat, an exhaustive search for $\gamma 3$ protein in non-neural tissue uncovered expression only in the pituitary, which has a neural element (Asano et al., 1995). A montage of cryosections assembled from a day 14.5 p.c. embryo shows the highly localized expression, specific to tissues derived from neuroectoderm (Fig. 4). Regions outside the brain enriched in $\gamma 3 \mathrm{mRNA}$ include the trigeminal ganglia, of which the sensory component is derived from the mesencephalic neural crest (Chan and Tam, 1988) and dorsal root ganglia (DRG, spinal ganglia), a derivative of trunk (spinal) neural crest cells that colonize at day 9.5-10.5 p.c. (Kubota et al., 1996), and in the prospective ear, the latter confirmed in rat by Barritt et al. (1999). Given the absolute conservation between the rat and mouse subunits (Fig. 1), it is interesting to note that $\gamma 3$ protein was not detected in the lateral chochlear wall of the adult rat (Khan et al., 2006). Rather than differences in staining between two closely related species, this discrepancy is likely a sensitivity issue between the immunocytochemistry methodology used by Khan et al. (2006), PCR in the study by Barritt et al. (1999) and in situ hybridization used in this study. Detailed analysis from cryosectioned material also showed $\gamma 3$ expression in the nose (Fig. 5A). Nuclear Fast Red counterstaining of sections following in situ hybridization shows the enrichment of $\gamma 3$ transcripts in the olfactory epithelia (Fig. 5B). Thus, by day 14.5 p.c. $\gamma 3$ staining was localized to the CNS, or neural crest cell (NCC) derivatives.

In situhybridization information is not available, but immunoblot analysis indicates that $\gamma 3$ protein is expressed in all regions of the adult rat brain, especially in the hippocampus, cerebellum, midbrain and hypothalamus (Asano et al., 1995), but not in the lateral habenula, lateral septal nucleus or Purkinje cells (Liang et al., 1998). It is interesting to note that $\gamma 3$ protein is present in the cerebral cortex of the adult rat, but is not detected in the embryo (Asano et al., 1995). $\gamma 3$ protein is strongly expressed in the cerebellum of the post-natal mouse, particularly in Purkinje cells, but staining declines in the adult (Schuller et al., 2001), which parallels that seen in the rat (Liang et al., 1998). Together, the results would indicate that as in adult rat (Asano et al., 1995) and bovine tissue (Cali et al., 1992, Gautam et al., 1990), 33 expression is also neural-specific in mouse embryos.

Analysis of other regions in the developing day 14.5 p.c. embryo reveals $\gamma 3$-containing cells throughout the spinal cord and near the genital tubercle (penis) (asterisk, Fig. 5C, D). Expression was also detected in the sympathetic nervous system, which is derived from trunk neural crest cells that migrate through the anterior parts of the somites and develop into a common faterestricted sympathoadrenal progenitor that differentiates into sympathetic ganglia and chromaffin cells (reviewed in Huber, 2006, Serbedzija etal., 1990). The extent of this expression at the base of the penis (asterisk, Fig. 5D), and flanking the blood-laden descending (thoracic) aorta (Figs. 5E), is more obvious in Nuclear Fast Red counterstained cryosections. In addition, $\gamma 3$ transcripts were also detected in the external layers of the stomach (arrows, Fig. 5D). Prevalent $\gamma 3$ expression was present in the DRG of embryos at day 14.5 p.c. (Fig. 6A, B). Counterstaining with Nuclear Fast Red shows $\gamma 3$ expression in the DRG, but not in vertebrae (Fig. 6B). Hybridization with a sense strand $\gamma 3$ control probe did not label any cells in the embryo (Fig. 6C).

Positive $\gamma 3$ staining was seen in the outer layer of the stomach, where signals were distributed in a punctate manner (Figs. 6D and $\mathrm{E}$ ). This region corresponds to the muscularis externa that

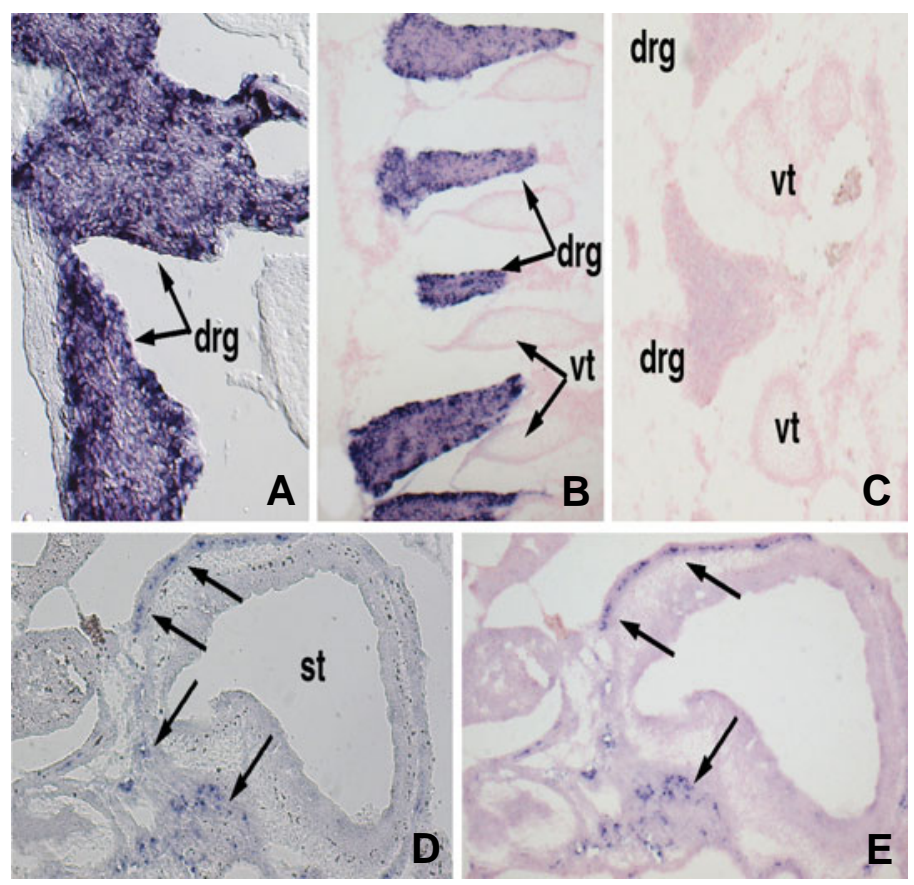

Fig. 6. $\boldsymbol{\gamma} \mathbf{3}$ expression in the dorsal root (spinal) ganglia and stomach. (A) DIC photomicrograph of a parasagittal section through the dorsal region of a day 14.5 p.C. embryo showing prominent expression in the dorsal root ganglia. (B) Brightfield image of a Nuclear Fast Red counterstained antisense $\gamma 3$-probed cryosection showing staining specificity in the dorsal root ganglia and not in vertebrae. (C) A brightfield image of a Nuclear Fast Red counterstained cryosection showing no signals when tissues were hybridized to a sense 33 probe. (D) Differential interference contrast image through the stomach shows discrete $\gamma 3$-positive cells (arrows) in the muscularis externa of the stomach. (E) The extent of expression is more obvious in a Nuclear Fast Red counterstained section. drg, dorsal root ganglia; st, stomach; vt, vertebra. 
includes the smooth muscle layers containing the neurons of the enteric nervous system that controls peristaltic movements. In a study to identify marker and candidate Hirschsprung disease genes, Heanue and Pachnis (2006) reported the expression of $\gamma 3$ in the enteric nervous system of mouse embryos at E11.5 and postnatal day 0 . The majority of enteric neurons originate from vagal and sacral neural crest cells that invade and migrate in the bowel wall of the fore and hindgut, respectively (reviewed in Heuckeroth and Pachnis, 2006). This is significant because once these cells invade, complex signaling mechanisms, that to date remain elusive, controls their migration, proliferation and differentiation into many different neuronal subtypes (Heanue and Pachnis, 2006). The contribution to this signaling by $\gamma 3$ is not known, but this subunit is coupled to L-type $\mathrm{Ca}^{2+}$ channel activity (MacrezLepretre et al., 1997), which has a major influence in the enteric nervous system (reviewed in Smith et al., 2003).

Analysis of whole mounts of late stage embryos show that the Gng3gene is strongly expressed in the CNS and PNS by day 16.5 p.c. (Fig. 7). Expression in the nose was not ubiquitous, but rather remained as in earlier stages, restricted to specific regions (Figs. $7 \mathrm{~B}$ and $8 \mathrm{~A}$ ). It is interesting to note that although signals were seen in the tongue, lungs and adrenals in day 16.5 embryos (Figs. $7 A, B$ and $8 A, B)$, expression of the protein was not reported in the adult organs (Asano et al., 1995). Our data showing the transcription of the Gng3 gene in cells in the tongue and prospective ear

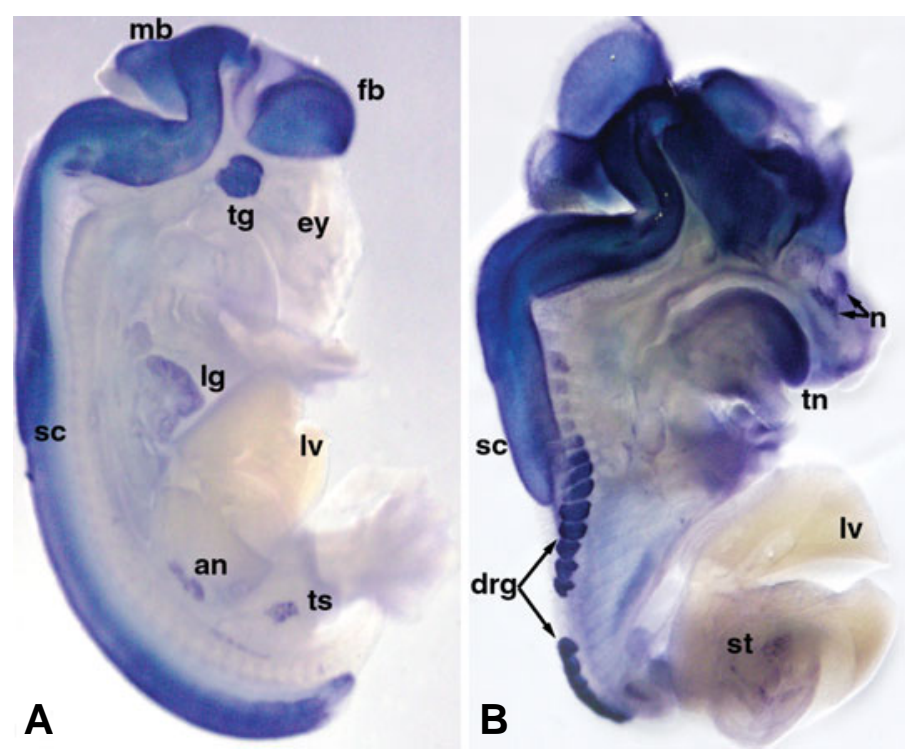

Fig. 7. Whole mount in situ hybridization showing the G-protein $\gamma 3$ expression pattern in mouse embryos at day $\mathbf{1 6 . 5}$ p.c. (A) A lateral, almost en face view shows $\gamma 3$ mRNA is preferentially expressed in the CNS. Other areas enriched with $\gamma 3$ transcripts include the trigeminal ganglia, lungs, adrenals and testes. At this stage, no y3-positive staining was seen in the eye or liver, or lateral areas of the nose (not shown). (B) Prior to hybridization this embryo was sliced sagittally, and at an oblique angle so that the rostral region appears more mid-sagittal than the remainder of the embryo. At this angle $\gamma 3$ signals are seen in the brain, spinal cord and in thoraco-abdominal dorsal root (spinal) ganglia. Labeling is prominent in the tongue and discrete areas in the nose (arrows), and weakly in the stomach. an, adrenal; ey, eye; drg, dorsal root ganglia; fb, forebrain; Ig, lung; Iv, liver; mb, midbrain; $n$, nose; sc, spinal cord; st, stomach; tn, tongue; tg, trigeminal ganglion; ts, testes. is not transient, since expression of the $\gamma 3$ protein was reported in adult rat circumvallate cells on the tongue (Rossler et al., 2000) and in adult mouse inner ear cells (Barritt et al., 1999). The possibility exists that expression in lungs and adrenals subsides following embryogenesis, but the more likely explanation is the difference in sensitivity between the detection methods used to identify the protein (Asano et al., 1995) or the transcript (this study).

The fact that $\gamma 3$ is more widely expressed than previously thought and is expressed outside neural tissue was recently brought to light by Dubeykovskiy et al. (2006). That Gng3/-mice exhibit a defective immune response prompted these authors to examine and find $\gamma 3$ expression in adult bone marrow, spleen and thymus of wild-type mice. Specifically, $\gamma 3$ is expressed in activated $\mathrm{CD}^{+}{ }^{+}$T-cells and in the spleen and bone marrow it is constitutively expressed in resting B-cells. Initially our identification of $\gamma 3$ in the embryonic adrenals supported the evidence that $\gamma 3$ is not neural-specific. Detailed analysis, however, shows that the transcripts were confined to the medullary region, which contains the splanchnic nerves that provides the sympathetic innervation to the chromaffin cells, which as described above are trunk neural crest derivatives. Positive staining in the sympathetic nerve trunk and in punctate regions of the enteric nervous system throughout the muscularis externa of the stomach, also highlight the contribution of trunk neural crest cells (Fig. 8C and D).

Our data on the temporal and spatial expression of the Gprotein $\gamma 3$ subunit is reminiscent of the pattern of expression seen in the zebrafish embryo, notably in the olfactory region of the brain, in the trigeminal ganglia and in the progenitors of the dorsal root ganglia (Kelly et al., 2001). Expression of $\gamma 3$ was also reported in the retinal ganglion cell layer in pre-hatching and hatching stages of zebrafish (Thisse and Thisse, 2004), and in the lens of the adult mouse (Tasheva et al., 2004). This expression in the eye is of interest because agonists of L-type $\mathrm{Ca}^{2+}$ channels induce large, propagating waves of neural activity required for the refinement of connections during development of the mouse retina (Singer et al., 2001). Modulating the activity of these $\mathrm{Ca}^{2+}$ channels in retinal ganglion cells and/or their presynaptic cells, is of paramount importance and mechanisms are in place to prevent an abnormal elevation of intracellular free $\mathrm{Ca}^{2+}$ that would lead to neuronal cell injury (Dong et al., 2007). Since $\gamma 3$ is involved in signaling associated with L-type $\mathrm{Ca}^{2+}$ channels (Macrez et al., 1997), any aberrant-activation of the - $\beta \gamma 3$ heterodimer would have grave consequences on neuronal cell viability, contributing to neurodegenerative disease and peripheral neuropathies. Finally, the appearance of $\gamma 3 \mathrm{mRNA}$ in the adrenals and gut was not reported in our investigation with zebrafish, which means a more detailed analysis of the interrenal tissue in fish requires further investigation.

Previous studies having reported the presence of $\gamma 3$ protein primarily in neural-specific tissues in the adult mouse brain, but this study is the first to detail the localization of the message during embryogenesis. It is interesting to note that outside the CNS, $\gamma$-expression is restricted to NCC derivatives, whose final fate and position is dependent on the contribution by multiple NCC populations. The widespread distribution of the $\gamma 3$-expressing cells in the body highlights the importance of $\beta \gamma$ signaling in a number of physiological processes. It is, however, surprising that with this distribution, the complex neurological and metabolic 


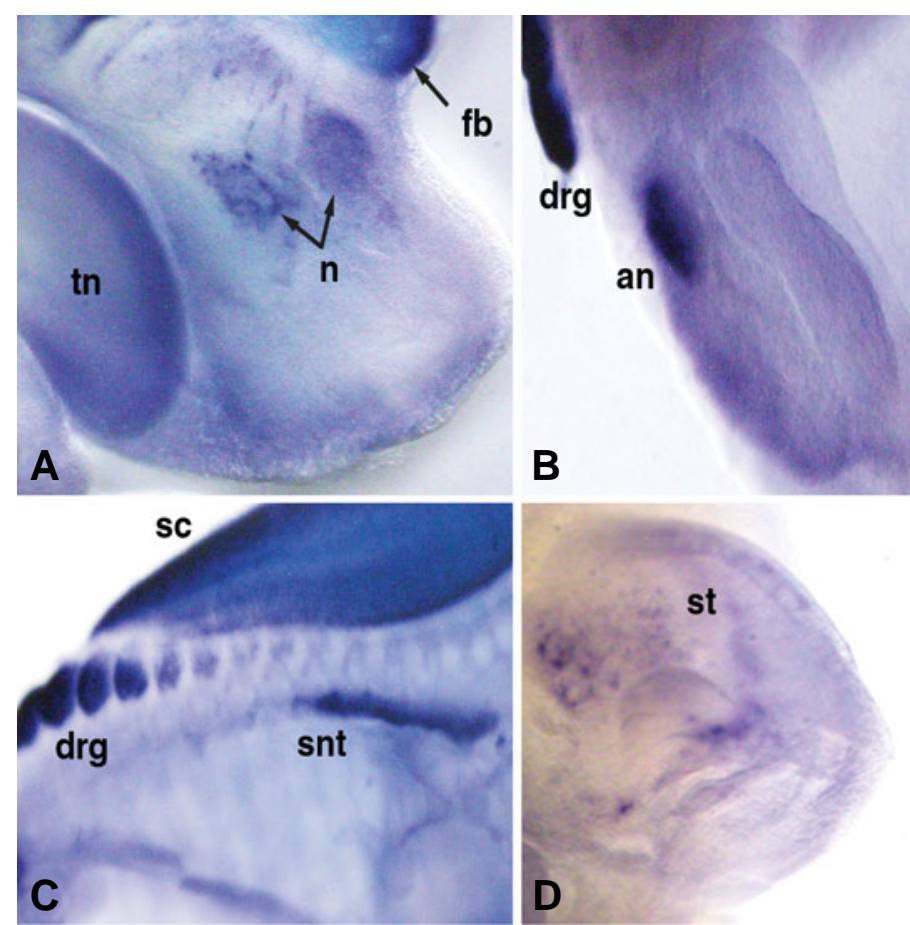

Fig. 8. In situ hybridization on whole mount embryos at day 16.5 p.c. showing specific $\gamma 3$ expression patterns in the CNS, PNS, adrenal and stomach. (A) Detailed view of the developing nose shows $\gamma 3$ signals in the olfactory epithelia (arrows), and in the layer of the tongue facing the oral cavity. (B) $\gamma 3$ is also expressed in the adrenals, specifically in the medullary region. (C) Photomicrograph showing the presence of $\gamma 3$ $m R N A$ in dorsal root (spinal) ganglia and the sympathetic nerve trunk. Spinal cord cells remain enriched with $\gamma 3$ mRNA at this and later stages of development. (D) Detailed examination of the stomach reveals discrete $\gamma 3$ signals, presumed to be in the muscularis externa. an, adrenal; drg, dorsal root ganglia; fb, forebrain; n, nose; sc, spinal cord; snt, sympathetic nerve trunk; st, stomach; tn, tongue.

abnormalities associated with the targeted disruption of the Gng3 gene (Schwindinger et al., 2004), would not have been more severe. That $\mathrm{Gng}^{\circ}$ mice experience a number of defects (Schwindinger et al., 2004), but survive embryogenesis, suggests functional redundancy and compensation by another $\gamma$ subunit (Malbon, 2005). Thus, the information presented herein on the unique expression patterns provides a blueprint by which to use conditional, double knock-outs to elucidate the tissue- and organspecific role(s) of $\gamma 3$ in the embryo and adult.

\section{Experimental Procedures}

\section{Reverse transcriptase-polymerase chain reaction}

For RT-PCR analysis total RNA was extracted from embryos together with their decidua (day 8.5 p.c.) or embryos alone (days 9.5 p.c. and later) using the TRIzol reagent (Life Technologies), as reported in Kelly and Reversade (Kelly and Reversade, 1997). Extracted RNA was precipitated in isopropanol, washed twice in $75 \%$ ethanol, then vacuum dried and resuspended in DEPC-treated glass distilled water (EM Science). Extracted RNA was quantified by spectrophotometry then electrophoresed on MOPS gels before being synthesized into first strand cDNA.

For first strand synthesis, $5 \mu \mathrm{g}$ of RNA from each pool was added to a reaction buffer (Roche Diagnostics) containing oligo dT primer and SuperScript II\%。 reverse transcriptase (RT) (Invitrogen, Life Technolo- gies). To control for genomic DNA contamination, primers were designed, spanning an intron, to sequences in exons 2 and 3 of the mouse Gng3 gene (Downes et al., 1998). All samples were incubated for $10 \mathrm{~min}$ at room temperature followed by $1 \mathrm{hr}$ at $42^{\circ} \mathrm{C}$. After $1 \mathrm{hr}$, samples were used directly in the PCR or stored at $-20^{\circ} \mathrm{C}$. To determine that $\gamma 3$ was not expressed prior to embryonic day 8.5 p.c., an aliquot from a mouse embryonic day 7-7.5 cDNA library was also used in the PCR.

For the PCR, samples containing Taq polymerase (Promega), and a sense 5'CAGCTTAAGATTGAGGCCAGC3' and antisense 5'CTGAAAGGGTGAGGAGATGG 3' oligodeoxynucleotide primer set, were subjected to the following conditions: $(1 \mathrm{cycle}) 94^{\circ} \mathrm{C}$ for 10 minutes, $55^{\circ} \mathrm{C}$ for 5 minutes, $72^{\circ} \mathrm{C}$ for 10 minutes; ( 40 cycles) $94^{\circ} \mathrm{C}$ for 30 seconds, $58^{\circ} \mathrm{C}$ for 60 seconds, $72^{\circ} \mathrm{C}$ for 90 seconds; $72^{\circ} \mathrm{C}$ for 10 minutes. Following the PCR a 320 base pair amplicon was expected based on the mouse $\gamma 3$ cDNA sequence (Accession \#NM_010316). Primers to the constitutively expressed $36 B 4$ gene (Krowczynska et al., 1989) were synthesized (sense 5'CAGCTCTGGAGAAACTGCTG3'; antisense 5'GTGTACTCAGTCTCCACAGA3') and used as a control to demonstrate that CDNA was present as template to be amplified in all samples. PCR products were analyzed by electrophoresis on $1 \%$ agarose gels containing ethidium bromide.

\section{In situ hybridization}

A plasmid containing an EST corresponding to mouse $\gamma 3$ (AA250316) was used to make DIG-labeled sense and antisense RNA probes for in situ hybridization. ICR females were mated to obtain different stages of development and detection of a vaginal plug was used to confirm pregnancy and staging at 0.5 days p.c. Embryos staged on the basis of their morphology at $\sim 7.5$ to 18.5 days p.c. were isolated, fixed in $4 \%$ paraformaldehyde and then processed for non-radioactive, whole mount in situ hybridization using standard procedures (Wilkinson, 1992). For detailed analysis, embryos at day 14.5 p.c. were fixed in $4 \%$ paraformaldehyde in phosphate buffered saline, incubated in increasing concentrations of sucrose and then embedded in OCT compound. Cryosections were prepared at a thickness of $10 \mu \mathrm{m}$ and collected on glass slides for in situ hybridization using the $\gamma 3$ probes described above. In some cases sections were counterstained with Nuclear Fast Red following hybridization. All images were captured with a digital camera and plates were assembled using Adobe Photoshop and Illustrator.

\section{Acknowledgements}

GMK would like to thank Dr. H. Hamada for providing space and Osaka University for funds to support a visiting professorship. The authors would also like to thank Drs. J. Nishino, K. Yashiro and D. Watanabe for expert advice, and K. Mochida, M. Nishijima for technical assistance. We would also like to thank Dr. A. Watson and A. Paliga for providing mouse embryos. This work was supported by grants from the Natural Sciences and Engineering Research Council of Canada to GMK.

\section{References}

ASANO, T., MORISHITA, R., OHASHI, K., NAGAHAMA, M., MIYAKE, T. and KATO, K. (1995). Localization of various forms of the gamma subunit of $G$ protein in neural and nonneural tissues. J Neurochem 64: 1267-73.

BARRITT, L.C., FRITZSCH, B. and BEISEL, K.W. (1999). Characterization of Gprotein betagamma expression in inner ear. Brain Res Mol Brain Res 68: 42-54.

CALI, J.J., BALCUEVA, E.A., RYBALKIN, I. and ROBISHAW, J.D. (1992). Selective tissue distribution of $G$ protein gamma subunits, including a new form of the gamma subunits identified by cDNA cloning. J Biol Chem 267: 24023-7.

CHAN, W.Y. and TAM, P.P. (1988). A morphological and experimental study of the mesencephalic neural crest cells in the mouse embryo using wheat germ agglutinin-gold conjugate as the cell marker. Development 102: 427-42.

DIVERSE-PIERLUISSI, M., MCINTIRE, W.E., MYUNG, C.S., LINDORFER, M.A., GARRISON, J.C., GOY, M.F. and DUNLAP, K. (2000). Selective coupling of G protein beta gamma complexes to inhibition of $\mathrm{Ca} 2+$ channels. JBio/ Chem275: 
28380-5.

DONG, C.-J., GUO, Y., WHEELER, L. and HARE, W.A. (2007). \{alpha\}2 Adrenergic Receptor-Mediated Modulation of Cytosolic $\mathrm{Ca}++$ Signals at the Inner Plexiform Layer of the Rat Retina. Invest Ophthalmol Vis Sci48: 1410-1415.

DOWNES, G.B., COPELAND, N.G., JENKINS, N.A. and GAUTAM, N. (1998). Structure and mapping of the $G$ protein gamma3 subunit gene and a divergently transcribed novel gene, gng3lg. Genomics 53: 220-30.

DRUMMOND, A., ASHTON, B., CHEUNG, M., HELED, J., KEARSE, M., MOIR, R., STONES-HAVAS, S., THIERER, T. and WILSON, A. (2007). Geneious v3.0. http://www.geneious.com/.

DUBEYKOVSKIY, A., MCWHINNEY, C. and ROBISHAW, J.D. (2006). Runxdependent regulation of G-protein gamma3 expression in T-cells. Cel/ Immuno/ 240: 86-95.

FARFEL, Z., BOURNE, H.R. and IIRI, T. (1999). The expanding spectrum of G protein diseases. N Eng/J Med 340: 1012-20.

GAUTAM, N., NORTHUP, J., TAMIR, H. and SIMON, M.I. (1990). G protein diversity is increased by associations with a variety of gamma subunits. Proc Natl Acad Sci USA 87: 7973-7.

GUDERMANN, T., GROSSE, R. and SCHULTZ, G. (2000). Contribution of receptor/G protein signaling to cell growth and transformation. Naunyn Schmiedebergs Arch Pharmaco/361: 345-62.

HEANUE, T.A. and PACHNIS, V. (2006). From the Cover: Expression profiling the developing mammalian enteric nervous system identifies marker and candidate Hirschsprung disease genes. Proc Natl Acad Sci USA 103: 6919-6924.

HEUCKEROTH, R.O. and PACHNIS, V. (2006). Getting to the guts of enteric nervous system development. Development 133: 2287-90.

HUBER, K. (2006). The sympathoadrenal cell lineage: specification, diversification, and new perspectives. Dev Bio/298: 335-43.

KALYANARAMAN, S., KALYANARAMAN, V. and GAUTAM, N. (1995). A brainspecific G protein gamma subunit. Biochem Biophys Res Commun216: 126-32.

KELLY, G.M. and REVERSADE, B. (1997). Characterization of a cDNA encoding a novel band 4.1-like protein in zebrafish. Biochem Cell Bio/75: 623-32.

KELLY, G.M., VANDERBELD, B., KRAWETZ, R. and MANGOS, S. (2001). Differential distribution of the $G$ protein gamma3 subunit in the developing zebrafish nervous system. Int J Dev Neurosci 19: 455-67.

KHAN, K.M., SARFARAZ, N., SIDDIQUI, S. and NAWAZ, H. (2006). Immunohistochemical localization of $G$ protein betagamma subunits in the lateral wall of the rat cochlea. J Anat 208: 205-18.

KLEUSS, C., SCHERUBL, H., HESCHELER, J., SCHULTZ, G. and WITTIG, B. (1993). Selectivity in signal transduction determined by gamma subunits of heterotrimeric G proteins. Science 259: 832-4.

KROWCZYNSKA, A.M., COUTTS, M., MAKRIDES, S. and BRAWERMAN, G. (1989). The mouse homologue of the human acidic ribosomal phosphoprotein PO: a highly conserved polypeptide that is under translational control. Nucleic Acids Res 17: 6408.

KUBOTA, Y., MORITA, T. and ITO, K. (1996). New monoclonal antibody (4E9R) identifies mouse neural crest cells. Dev Dyn 206: 368-78.

LIANG, J.J., COCKETT, M. and KHAWAJA, X.Z. (1998). Immunohistochemical localization of $\mathrm{G}$ protein beta1, beta2, beta3, beta4, beta5, and gamma3 subunits in the adult rat brain. J Neurochem 71: 345-55.

MACREZ, N., MOREL, J.L., KALKBRENNER, F., VIARD, P., SCHULTZ, G. and MIRONNEAU, J. (1997). A betagamma dimer derived from G13 transduces the angiotensin $\mathrm{AT} 1$ receptor signal to stimulation of $\mathrm{Ca} 2+$ channels in rat portal vein myocytes. J Biol Chem 272: 23180-5.

MACREZ-LEPRETRE, N., KALKBRENNER, F., MOREL, J.L., SCHULTZ, G. and MIRONNEAU, J. (1997). G protein heterotrimer Galpha13beta1 gamma3 couples the angiotensin AT1A receptor to increases in cytoplasmic $\mathrm{Ca} 2+$ in rat portal vein myocytes. J Biol Chem 272: 10095-102.

MALBON, C.C. (2005). G proteins in development. Nat Rev Mol Cell Bio/6: 689701.

MARINISSEN, M.J. and GUTKIND, J.S. (2001). G-protein-coupled receptors and signaling networks: emerging paradigms. Trends Pharmaco/ Sci22: 368-76.

MARRARI, Y., CROUTHAMEL, M., IRANNEJAD, R. and WEDEGAERTNER, P.B. (2007). Assembly and trafficking of heterotrimeric G proteins. Biochemistry 46: 7665-77.

MIKKELSEN, T.S., WAKEFIELD, M.J., AKEN, B., AMEMIYA, C.T., CHANG, J.L., DUKE, S., GARBER, M., GENTLES, A.J., GOODSTADT, L., HEGER, A. et al. (2007). Genome of the marsupial Monodelphis domestica reveals innovation in non-coding sequences. Nature 447: 167-77.

MORISHITA, R., SAGA, S., KAWAMURA, N., HASHIZUME, Y., INAGAKI, T., KATO, K. and ASANO, T. (1997). Differential localization of the gamma 3 and gamma 12 subunits of $G$ proteins in the mammalian brain. JNeurochem 68: 8207

MORISHITA, R., SHINOHARA, H., UEDA, H., KATO, K. and ASANO, T. (1999). High expression of the gamma 5 isoform of $G$ protein in neuroepithelial cells and its replacement of the gamma2 isoform during neuronal differentiation in the rat brain. J Neurochem 73: 2369-74.

MORRIS, A.J. and MALBON, C.C. (1999). Physiological regulation of G proteinlinked signaling. Physiol Rev 79: 1373-430.

MYUNG, C.S., LIM, W.K., DEFILIPPO, J.M., YASUDA, H., NEUBIG, R.R. and GARRISON, J.C. (2006). Regions in the G protein gamma subunit important for interaction with receptors and effectors. Mol Pharmaco/69: 877-87.

MYUNG, C.S., YASUDA, H., LIU, W.W., HARDEN, T.K. and GARRISON, J.C. (1999). Role of isoprenoid lipids on the heterotrimeric $G$ protein gamma subunit in determining effector activation. J Biol Chem 274: 16595-603.

ROSSLER, P., BOEKHOFF, I., TAREILUS, E., BECK, S., BREER, H. and FREITAG, J. (2000). G protein betagamma complexes in circumvallate taste cells involved in bitter transduction. Chem Senses 25: 413-21.

SCHILLO, S., BELUSIC, G., HARTMANN, K., FRANZ, C., KUHL, B., BRENNERWEISS, G., PAULSEN, R. and HUBER, A. (2004). Targeted mutagenesis of the farnesylation site of Drosophila Ggammae disrupts membrane association of the $G$ protein betagamma complex and affects the light sensitivity of the visual system. J Biol Chem 279: 36309-16.

SCHULLER, U., LAMP, E.C. and SCHILLING, K. (2001). Developmental expression of heterotrimeric G-proteins in the murine cerebellar cortex. Histochem Cell Biol 116: 149-59.

SCHWINDINGER, W.F., GIGER, K.E., BETZ, K.S., STAUFFER, A.M., SUNDERLIN, E.M., SIM-SELLEY, L.J., SELLEY, D.E., BRONSON, S.K. and ROBISHAW, J.D. (2004). Mice with deficiency of $G$ protein gamma3 are lean and have seizures. Mol Cell Bio/24: 7758-68.

SERBEDZIJA, G.N., FRASER, S.E. and BRONNER-FRASER, M. (1990). Pathways of trunk neural crest cell migration in the mouse embryo as revealed by vital dye labelling. Development 108: 605-12.

SINGER, J.H., MIROTZNIK, R.R. and FELLER, M.B. (2001). Potentiation of L-type calcium channels reveals nonsynaptic mechanisms that correlate spontaneous activity in the developing mammalian retina. J Neurosci21: 8514-22.

SMITH, T.K., KANG, S.H. and VANDEN BERGHE, P. (2003). Calcium channels in enteric neurons. Curr Opin Pharmaco/3: 588-93.

TASHEVA, E.S., KE, A., DENG, Y., JUN, C., TAKEMOTO, L.J., KOESTER, A. and CONRAD, G.W. (2004). Differentially expressed genes in the lens of mimecannull mice. Mol Vis 10: 403-16.

THISSE, B. and THISSE, C. (2004). Fast Release Clones: A High Throughput Expression Analysis. ZFIN Direct Data Submission (http://zfin.org).

WILKINSON, D.G. (1992). Whole mount in situ hybridization of vertebrate embryos. In: Wilkinson, D.G. (Ed.). In situ hybridization: a practical approach. IRL Press, Oxford, UK, pp. 78-84.

YAN, K., KALYANARAMAN, V. and GAUTAM, N. (1996). Differential ability to form the $G$ protein betagamma complex among members of the beta and gamma subunit families. J Biol Chem 271: 7141-6.

ZHOU, J.Y., SIDEROVSKI, D.P. and MILLER, R.J. (2000). Selective regulation of $\mathrm{N}$-type $\mathrm{Ca}$ channels by different combinations of G-protein beta/gamma subunits and RGS proteins. J Neurosci20: 7143-8. 


\section{Further Related Reading, published previously in the Int. J. Dev. Biol.}

See our recent Special Issue Fertilization, in honor of David L. Garbers and edited by Paul M. Wassarman and Victor D. Vacquier at: http://www.ijdb.ehu.es/web/contents.php?vol=52\&issue=5-6

See our Special Issue The Nogent Institute, in honor of Nicole Le Douarin and edited by Francoise Dieterlen at: http://www.ijdb.ehu.es/web/contents.php?vol=49\&issue=2-3

Pax7 identifies neural crest, chromatophore lineages and pigment stem cells during zebrafish development Ana M Lacosta, Jesús Canudas, Cristina González, Pedro Muniesa, Manuel Sarasa and Luis Domínguez Int. J. Dev. Biol. (2007) 51: 327-331

Fate of cranial neural crest cells during craniofacial development in endothelin-A receptor-deficient mice Makoto Abe, Louis-Bruno Ruest and David E. Clouthier

Int. J. Dev. Biol. (2007) 51: 97-105

The instability of the neural crest phenotypes: Schwann cells can differentiate into myofibroblasts

Carla Real, Corinne Glavieux-Pardanaud, Pierre Vaigot, Nicole Le Douarin and Elisabeth Dupin

Int. J. Dev. Biol. (2005) 49: 151-159

Migration of neural crest-derived enteric nervous system precursor cells to and within the gastrointestinal tract

Alan J. Burns

Int. J. Dev. Biol. (2005) 49: 143-150

Early stages of neural crest ontogeny: formation and regulation of cell delamination

Chaya Kalcheim and Tal Burstyn-Cohen

Int. J. Dev. Biol. (2005) 49: 105-116

Genetic disruption of the growth hormone receptor does not influence motoneuron survival in the developing mouse.

Sean A Parsons, Glen B Banks, Jenny A Rowland, Karen T Coschigano, John J

Kopchick, Michael J Waters and Peter G Noakes

Int. J. Dev. Biol. (2003) 47: 41-49

Development and function of bombesin-like peptides and their Involvement of endothelin receptors in normal and pathological development of neural crest cells. Patrick Pla and Lionel Larue

Int. J. Dev. Biol. (2003) 47: 315-325

Patterns of migration and regulation of trunk neural crest cells in zebrafish (Danio rerio).

$\mathrm{J} L$ Vaglia and B K Hall

Int. J. Dev. Biol. (2000) 44: 867-881

The LIM homeodomain protein Lim-1 is widely expressed in neural, neural crest and mesoderm derivatives in vertebrate development.

A A Karavanov, J P Saint-Jeannet, I Karavanova, M Taira and I B Dawid Int. J. Dev. Biol. (1996) 40: 453-461

Early events in the histo- and cytogenesis of the vertebrate CNS.

$J$ Nakai and S Fujita

Int. J. Dev. Biol. (1994) 38: 175-183

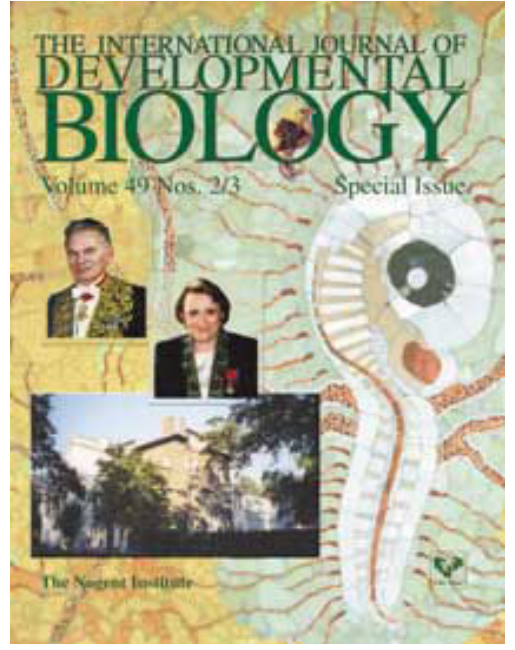

2006 ISI **Impact Factor $=3.577^{* *}$

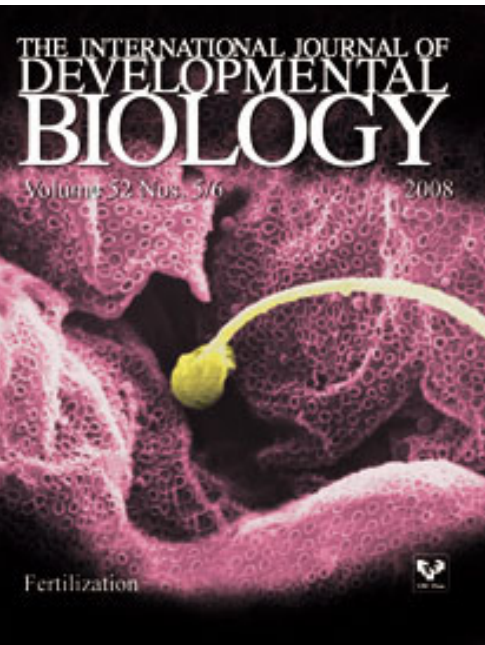

